\title{
Isolation and identification of microscopic fungi of agricultural importance in the Tetillas hill in Salvatierra, Guanajuato
}

\section{Aislamiento e identificación de hongos microscópicos de importancia agrícola en el cerro Tetillas en Salvatierra, Guanajuato}

\author{
MARTÍNEZ-SCOTT, Marcia Maribel $\dagger^{*}$, ZÚÑIGA-MALDONADO, Walter Manuel and MORENO- \\ ZACARÍAS, Pedro Eduardo
}

Instituto Tecnológico Superior de Salvatierra, Innovación Agrícola Sustentable. Calle Manuel Gómez Morín \#300, Col. Janicho, Salvatierra Gto, CP. 38933

ID $1^{\text {st }}$ Author: Marcia Maribel, Martínez-Scott / ORC ID: 0000-0002-5219-0016, Researcher ID Thomson: X-4047-2018, CVU CONACYT ID: 168569

ID $1^{\text {st }}$ Co-author: Walter Manuel, Zúñiga-Maldonado / ORC ID: 0000-0003-1140-4628, Researcher ID Thomson: X-95112019, CVU CONACYT ID: 509491

ID 2 $2^{\text {nd }}$ Co-author: Pedro Eduardo, Moreno-Zacarías / ORC ID: 0000-0003-4904-4824, CVU CONACYT ID: 428055

DOI: $10.35429 / J Q S A .2021 .23 .8 .1 .16$

Received March 14, 2021; Accepted June 29, 2021

\begin{abstract}
This research was throughout 2018-2020, filamentous fungi of agricultural importance were isolated from the Cerro Las Tetillas, located in the municipality of Salvatierra, Guanajuato. The hill was divided into three strata: upper, middle and lower. Two hundred soil samples were taken at depths of 0-15 and $15-30 \mathrm{~cm}$. These were processed in the biology laboratory, belonging to the Higher Technological Institute of Salvatierra. Two isolation techniques were used: direct seeding and serial dilutions, over Petri dishes with potato dextrose agar culture medium and $100 \mathrm{mg}$ of streptomycin to control bacteria. One hundred and thirteen axenic strains corresponding to 16 genera identified from "Cerro Tetillas" were obtained. At the upper stratum, 13 genera were identified, while in the middle and lower strata, nine genera were identified in each one of them. The diversity of soil fungi found in the different strata of the hill may be due to physicochemical characteristics of soil, native vegetation, interaction and abundance of soil fungi species, human disturbance and rain runoff.
\end{abstract}

Native isolates, Identification, Filamentous fungi

\begin{abstract}
Resumen
Esta investigación se realizó durante los años 20182020, se aislaron hongos filamentosos de importancia agrícola en el cerro las Tetillas, ubicado en el municipio de Salvatierra, Guanajuato. El cerro se dividió en tres estratos: parte alta, media y baja. Se tomaron 200 muestras de suelo a profundidades de $0-15$ y $15-30 \mathrm{~cm}$. Estas fueron procesadas en el laboratorio de biología, perteneciente al Instituto Tecnológico Superior de Salvatierra. Se utilizaron dos técnicas de aislamiento: siembra directa y diluciones seriadas esparcidas en cajas de Petri conteniendo medio de cultivo papa dextrosa agar y $100 \mathrm{mg}$ de estreptomicina para el control de bacterias. Se obtuvieron 113 cepas axénicas correspondientes a 16 géneros identificados del "Cerro Tetillas”. En el estrato alto se identificaron 13 géneros, mientras que en el medio y bajo, fueron identificados nueve géneros en cada uno de ellos. La diversidad de los hongos del suelo encontrada en los diferentes estratos del cerro puede estar supeditada a características fisicoquímicas del suelo, a la vegetación, a la interacción y abundancia de las especies presentes, a la perturbación del hombre y a los escurrimientos pluviales.
\end{abstract}

Aislamientos nativos, Identificación, Hongos filamentosos

Citation: MARTÍNEZ-SCOTT, Marcia Maribel, ZÚÑIGA-MALDONADO, Walter Manuel and MORENO-ZACARÍAS, Pedro Eduardo. Isolation and identification of microscopic fungi of agricultural importance in the Tetillas hill in Salvatierra, Guanajuato. Journal of Quantitative and Statistical Analysis. 2021. 8-23: 1-16

\footnotetext{
* Correspondence to Author (e-mail: mascott@itess.edu.mx)

$\dagger$ Researcher contributing as first author.
} 


\section{Introduction}

Mexico have a lot of geographical locations therefore, provide diversity of ecosystems that allows environmental and microenvironmental conditions that promote a great variety of habitats and life forms, in addition to a natural richness in terms of groups of organisms and high biological diversity of soil microorganisms, placing it in fifth place worldwide for its large number of species and endemisms, which contributes to $10 \%$ of the terrestrial diversity of theplanet (Aguirre-Acosta et al., 2014). Within thisgreat biological diversity of the soils, Fungi kingdom stands out, representing one of the largest biodiversity reservoirs with crucial ecological activities in all ecosystems with great variability in morphology and life cycles, those population is greater in biomass than bacteria. However, such populations are contingent on factors such as availability of water and nutrients, soil type and depth, that enable their growth and development, (Lavelle \& Spain, 2001; Pescasa-Quisbert, 2017), besides their interspecific relationships with other communities of microorganisms (Sivila \& Hervé 1999, Cabello \& Arambarri, 2002).

In soil, fungi interact with complex microbial community that includes: bacteria, actinomycetes and small invertebrates, being an important part of the soil food chain, mainly for the mesofauna that inhabit in it, which includes saprophytic species that play a crucial role in the decomposition of plant structural polymers, such as cellulose, hemicellulose and lignin, contributing to the maintenance of carbon cycles and other nutrients (Domsch et al., 2007; Bonkowski et al., 2000).

México has approximately 200,000 species of fungi (Hawksworth 2001) and only $5 \%$ of them has been identified; the states of Veracruz, Jalisco and theState of Mexico have the largest number of records. Although the soil harbors aconsiderable fungal population, there are no reliable estimates of the number of fungal species that inhabit in it. There are currently no records of research concerning to the soil diversity of filamentous fungi in Salvatierra, Guanajuato, including Cerro las Tetillas, made up of volcanic materials, mostly of the basaltic genus, a dark, reddish rock of a porous nature, called tezontle, that allows rainwater to infiltrate to deep levels,causing landslides during the rainy season (June-October).
This complex of two hills has both areas undisturbed and disturbed by human activity in the northern part by the overexploitation of a tezontle bank, an activity that destroys the habitat of unknown native organismsthat could be a source of soil natural health. Phytopathogenic and biocontrol fungi of agricultural interest that may be in danger of extinction (Conabio, 2019). These microorganisms may be interacting on the endemic fauna and flora of the region and require isolation and identification of agriculturally important species before they disappear due to overexploitation.

\section{Methodology}

\section{Establishment of the study area}

The study area was located in the Tetillas hill in the municipality of Salvatierra, Gto. Latitude: $20^{\circ} 12^{\prime} 13.2^{\prime \prime}\left(20.2037^{\circ}\right)$ north, Longitude: $100^{\circ}$ 55' 37.9" $\left(100.9272^{\circ}\right)$ west. Altitude: 2158 meters (7080 feet). The maximum temperature is $33.4{ }^{\circ} \mathrm{C}$ and the annual average is $18.1{ }^{\circ} \mathrm{C}$; the minimum is $2^{\circ} \mathrm{C}$. Rainfall is 730 millimeters per year. Figure 1 shows the two complexes of Cerro Tetillas.

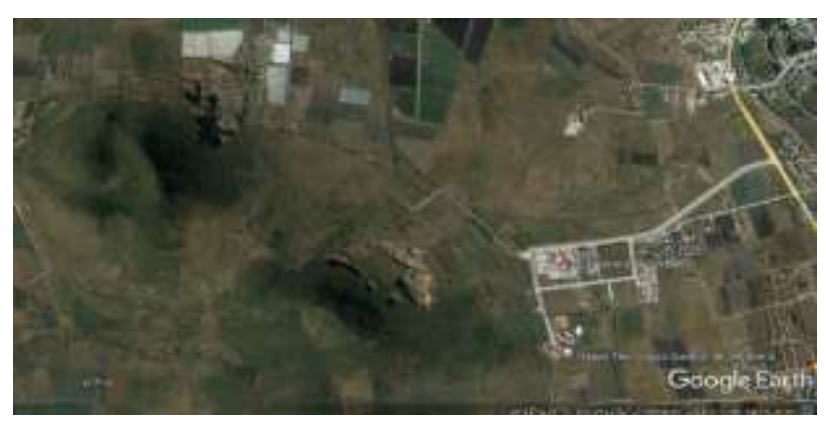

Figure 1 Location of the study area "Cerro Tetillas" Salvatierra, Gto.

Source: Google Earth Pro Version 7.34 Google LLC (C)2021

\section{Soil Sampling}

The hill was divided into three strata (low, medium and high). Sixty-five reference points were selected in each stratum, collecting 200 composite samples taken at depths of 0-15 and 15-30 cm, which were carried to the biology laboratory at the Instituto Tecnológico Superiorde Salvatierra for drying and processing according to Mexican Official Standard NOM- 021-SEMARNAT-2000. The hydrogen potential $(\mathrm{pH})$, electrical conductivity (E.C.) and colorimetry of the soils were determined using Munsell's keys. 


\section{Isolation of fungi}

The isolation techniques of direct soil seeding and serial dilutions were used. The first technique, $50 \mathrm{mg}$ of soil were taken, andspread directly on plates with PDA containing $100 \mathrm{mg}$ of streptomycin/L (Santander et al., 2003), and left to stand for three days at a temperature of $25 \pm 1{ }^{\circ} \mathrm{C}$, (Barrón, 1977; Muelleret al., 2004).

Serial dilutions were from $10^{-1}$ to $10^{-5}$, serial dilutions shaking for five minutes, subsequently an aliquot of $(0.1 \mathrm{ml})$ wastaken and distributed on the plate with PDAmedium and incubated for three to five days at room temperature of $25 \pm 1{ }^{\circ} \mathrm{C}$. The grown colonies were transferred to new plates with medium until axenic and isolates were obtained. Pure cultures were transferred to plates with selective media and incubated for 10 days to promote sporulation and proceed to identification (Edel et al., 2001; Tsao et al., 1983; Valencia, 1979).

\section{Description of fungal growth}

Fungi colonies, were described according to Watanabe technique (2010), describing the axenic growth of the fungus seven days after sowing, both on the front and back of the Petri dish. At front side, the following were recorded: a) color of the surface and outline of the colony, b) texture, c) color of the exuded pigment and d) shape of the colony and margin. On reverse side, we recorded: a) color of theinner, middle and edge of the colony, b) inner surface and c) outer surface of the colony.

\section{Identification}

Morphological identification was carried out using taxonomic keys (Barnett and Hunter; 1998, Domsch et al., 1980; Gams and Bissett, 1998; Bissett, 1984; Dick, 1990, Gams et al, 1985), specialized literature, as well as internet photographs of fungi grown in various culture media and some identification manuals and taxonomic Catalogs of fungal species in Mexico (Cifuentes, 2008), as well as entomopathogenic fungi production manuals of SENASICA and SENASA and other manuals (Bissett, 1991; Humber, 1998, Leslie et al., 2006; Pfenningy Magalhães, 2012; Piontelli, 2012; Rodríguez, 2001). Soil Sampling.

\section{Results}

In Graphic 1, C.E and $\mathrm{pH}$ values found in the three strata of the hill are observed. The soils show similar $\mathrm{pH}$, while the E.C. values are higher in the lower stratum, which could be translated into a higher concentration of salts, probably because Cerro las Tetillas is a natural source of red tezontle, hence the predominance of this type of color. However, in the lower stratum, the predominant color of the soil is grayish, and at greater depth it changes from yellow to brown. The greatest richness of fungi identified was concentrated in the upper part of the hill, perhaps because this is where there is less disturbance by humans and where the E.C. and pH is lower.

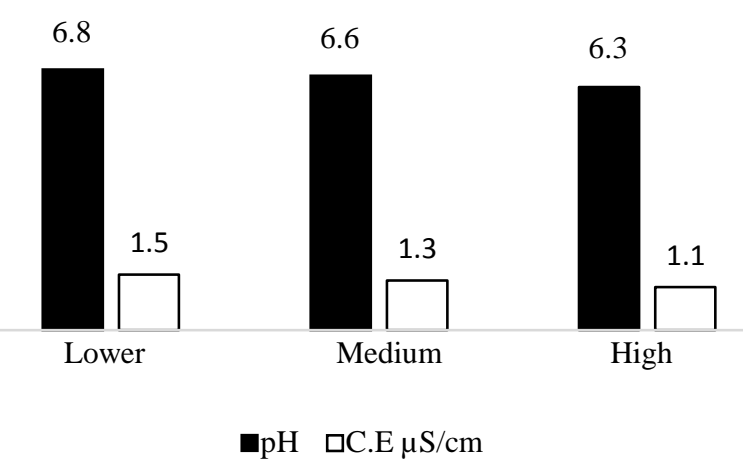

Graphic 1 Mean values of electrical conductivity (E.C.) and hydrogen potential $(\mathrm{pH})$ by strata.

\section{Isolation of fungi by stratum}

The following table shows the genera found by stratum.

\begin{tabular}{|l|l|l|l|}
\hline \multicolumn{2}{|c|}{ Uenres } & \multicolumn{3}{c|}{$\begin{array}{l}\text { Strata } \\
\text { Medium }\end{array}$} & High \\
\hline Alternaria & & $*$ & \\
\hline Aspergillus & $* *$ & $* *$ & $* *$ \\
\hline Beauveria & & $* *$ & $* *$ \\
\hline Cladosporium & $* *$ & & \\
\hline Colletotrichum & $* *$ & $* *$ & $* *$ \\
\hline Fusarium & $* *$ & $* *$ & $* *$ \\
\hline Lecanicillium & & & $*$ \\
\hline Metarhizium & & & $* *$ \\
\hline Mucor & & & $*$ \\
\hline Paecilomyces & & $* *$ & \\
\hline Penicillium & $* *$ & $* *$ & $* *$ \\
\hline Phytophthora & $* *$ & & $*$ \\
\hline Phytium & $* *$ & $* *$ & $*$ \\
\hline Trichoderma & $* *$ & $* *$ & $* *$ \\
\hline Trichophyton & & & $*$ \\
\hline Verticillium & $*$ & & $*$ \\
\hline
\end{tabular}

* Presence of the fungus

**Abundance of isolates obtained

Table 1 Presence of identified genera of filamentous fungi by stratum of Cerro las Tetillas

Source: Martínez-Scott, 2020 


\section{Description of the identified genera}

\section{Alternaria}

Flat and cottony colonies, initially white in color, turning grayish in PDA medium after sporulation and with the passage of days showed a change of color that varied from various shades of brown to dark olive-green, the back of the colony showed a dark brown-black color with cream edges as shown in the following figure.

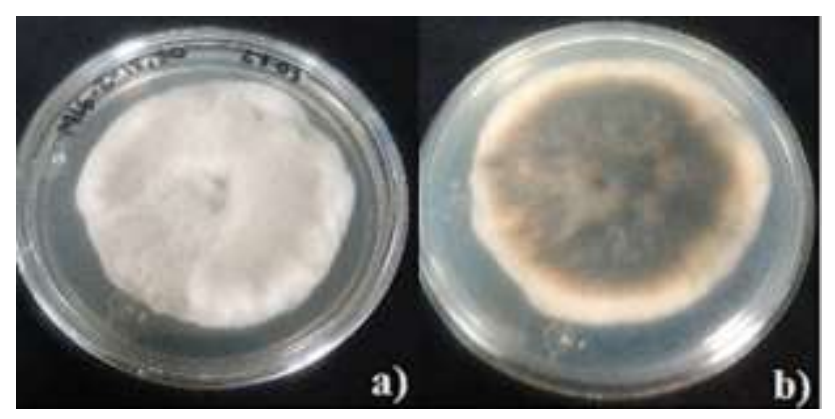

Figure 2 Macroscopic characteristics of the fungus Alternaria $s p$

Source: (Martinez-Scott, 2020)

Well-developed septate hyphae, with erect, short, dichotomously branched, geniculate, somewhat swollen conidiophores near the apices, subhyaline or pale, with conidia at the nodes. Conidia showed ovoid or ellipsoidal shapes, simple or branched, often with a small hilum, dark olive to black, warty, with transverse, oblique and longitudinal septa (Cruz et al., 2016).

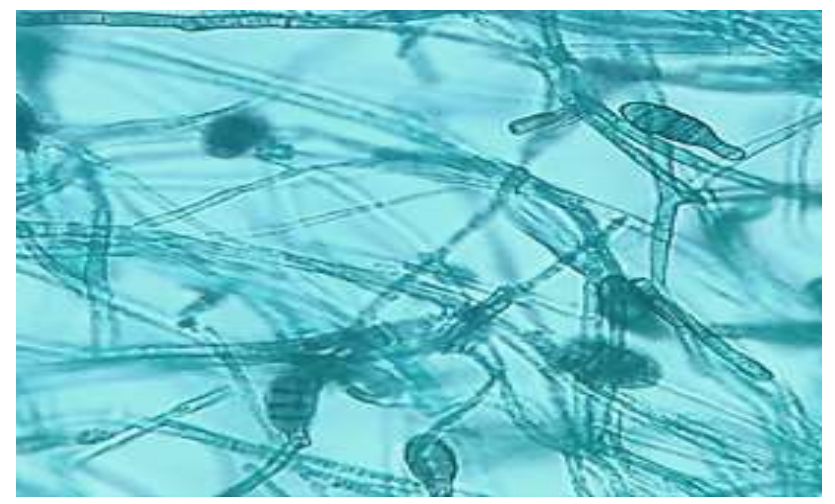

Figure 3 Observation of multicellular conidia, with transverse and longitudinal septa of Alternaria sp. (40X magnification)

Source: (Martinez-Scott, 2020)

\section{Aspergillus}

According to the macro and microscopic characteristics described by Pier Antonio Micheli in 1729, flat colonies of velvety or powdery texture were observed, with different irregular growth in each isolate; in addition, colonies were black, white, beige, and the reverse side showed dark brown, cream-grayishtan and brown colors, absent of exudation, concordant with that described by Rodríguez et al. (2007).

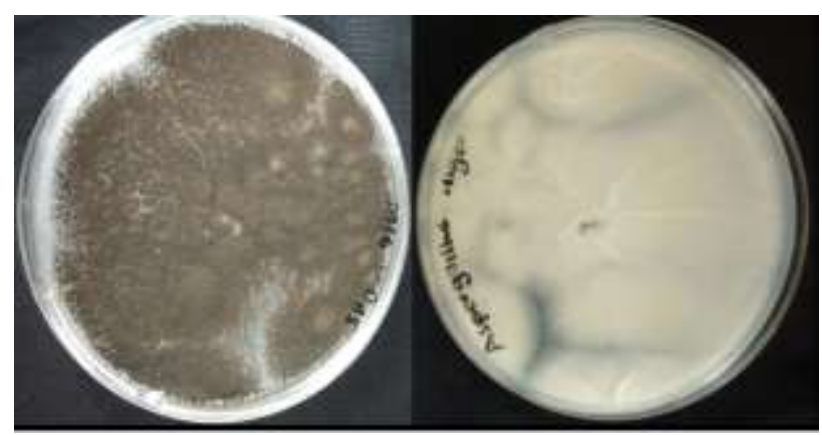

Figure 4 Macroscopic characteristics of the fungus Aspergillus $s p$

Source: Martinez-Scott, 2021)

In Aspergillus isolates, biseriate conidial heads were observed in compact columns; smooth-walled, hyaline stipes. Vesicles variable in shape, spherical or subglobose; metulae occupying half or two thirds of the vesicle. Conidia smooth, globose or subglobose and beveled (Abarca, 2000).

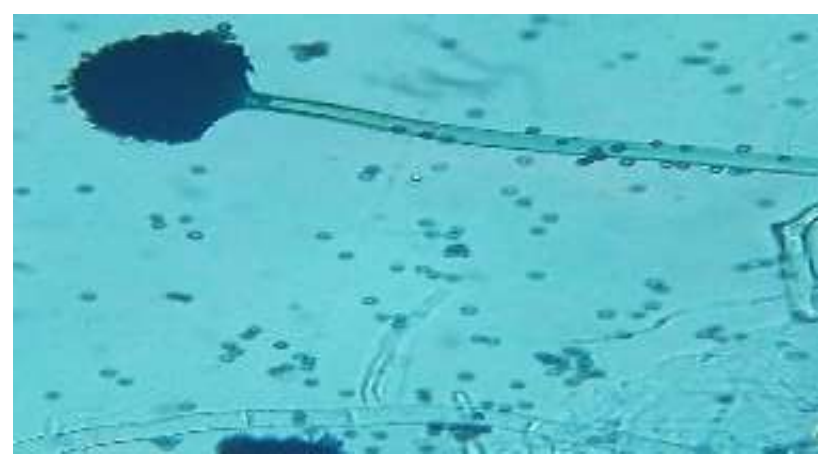

Figure 5 Observation of microscopic structures (conidial heads) of Aspergillus sp. (magnification 40X) Source: (Martinez-Scott, 2020)

\section{Beauveria}

The isolates of this genus presented a slow, circular growth, reaching $20 \mathrm{~mm}$ in diameter in 10 days, which coincides with that established by Vuillemin in 1912, cited by Domsch et al. (2007). 
The appearance of the colony is woolly and powdery due to the abundant white conidia that formed at the beginning and later became yellowish in the center. These characteristics are variable, so they are not considered as the only criteria to determine the species. The isolates produced yellow pigmentation diffusing in the medium, probably due to the presence of bauvericin, a toxin secreted by $B$. bassiana and $B$. brongniartti during growth, according to Vargas (2003).

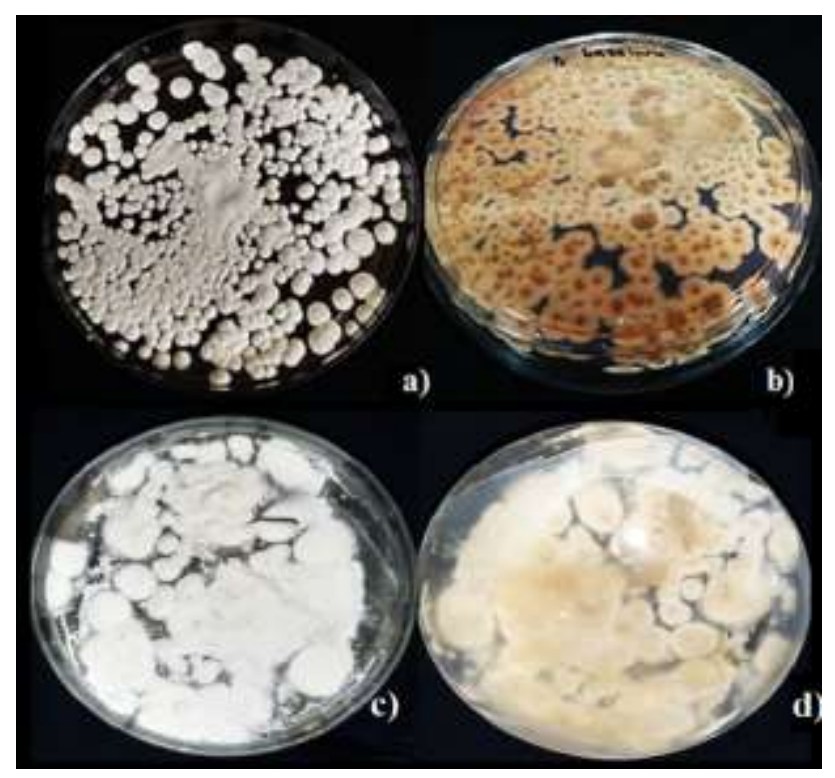

Figure 6 Macroscopic characteristics of the fungus Beauveria sp. a and b) front and back on PDA and Sabouraud Agar c) and d) at seven days after sowing Source: (Martinez-Scott, 2020)

The microscopic characteristics of some isolates presented globose to subglobose conidia, the conidiophore structures formed dense groups, as described by Samson et al. All strains formed efficient synemas (elongated branched structures) for conidia dispersal, indicating that these strains would be potential biocontrollers of agricultural pests.

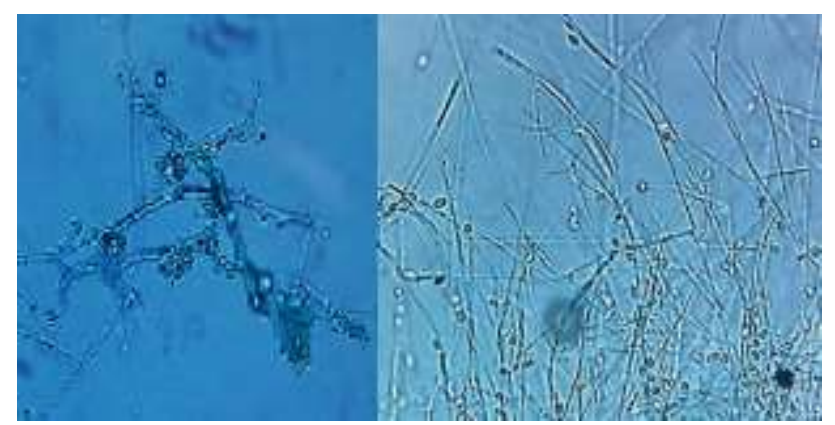

Figure 7 Microscopic structures of two isolates of Beauveria sp (40X magnification)

Source (Martínez-Scott, 2020)

\section{Cladosporium}

In 1816 Link described Cladosporium colonies as having a velvety or floccose texture and olivebrown to brownish-black colors because their vegetative hyphae, conidiophores and conidia are pigmented in agreement with the isolates obtained. Figure 8 shows the filling of the box of isolate M12.1.

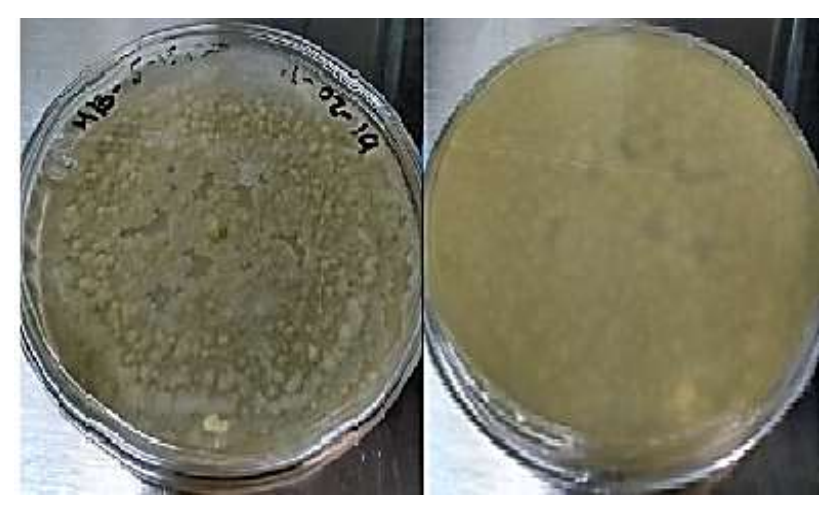

Figure 8 Macroscopic characteristics of the fungus Cladosporium sp on PDA

Source (Martínez-Scott, 2020)

Figure 9 shows conidiophores more or less differentiated from vegetative hyphae, erect or flexuous, sometimes branched. In addition, the presence of blastoconidia of one or two cells, variable in shape and size, from ovoid to cylindrical and irregular, some lemon-shaped, can be denoted.

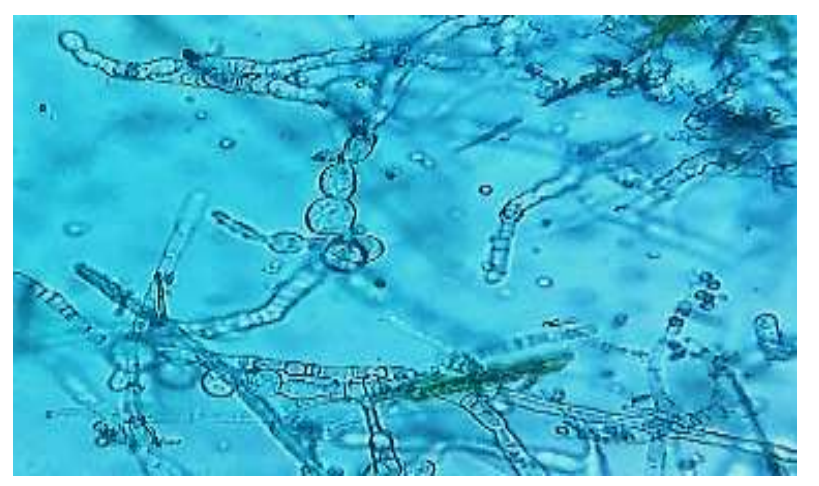

Figure 9 Observation of microscopic structures of Cladosporium sp

Source (Martínez-Scott, 2020)

\section{Colletotrichum}

Isolates of the genus Colletotrichum grow easily on PDA, initially the colony is creamy and salmon-colored, emitting a white mycelium on its edges that eventually became grayish, its full development was reached after 15 days at a temperature of $25 \pm 1{ }^{\circ} \mathrm{C}$, results consistent with those reported by Bailey and Jeger, (1992). 
Figures 10 and 11 show the macro and microscopic structures of isolate M12.1.

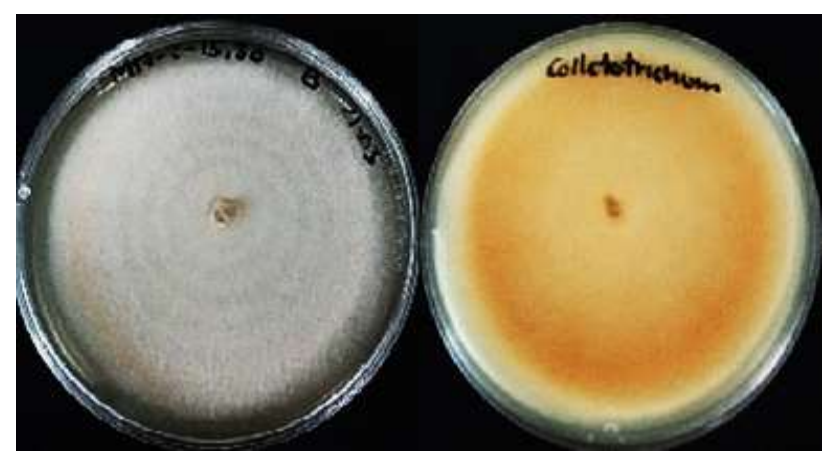

Figure 10 Macroscopic characteristics of the fungus Colletotrichum $s p$

Source (Martínez-Scott, 2020)

This genus, morphologically, presents hyaline conidia $(7-20 \times 2.5-5 \mu \mathrm{m})$, unicellular and fusiform that are located in a reproductive structure called acervulus. These bodies are discshaped, waxy, subepidermal. Besides presenting conidiophores and conidia, the fungus presents setae on the edge of the acervulus or between conidiophores, although sometimes they are absent (Bailey and Jeger, 1992 cited by Botero, 1999).

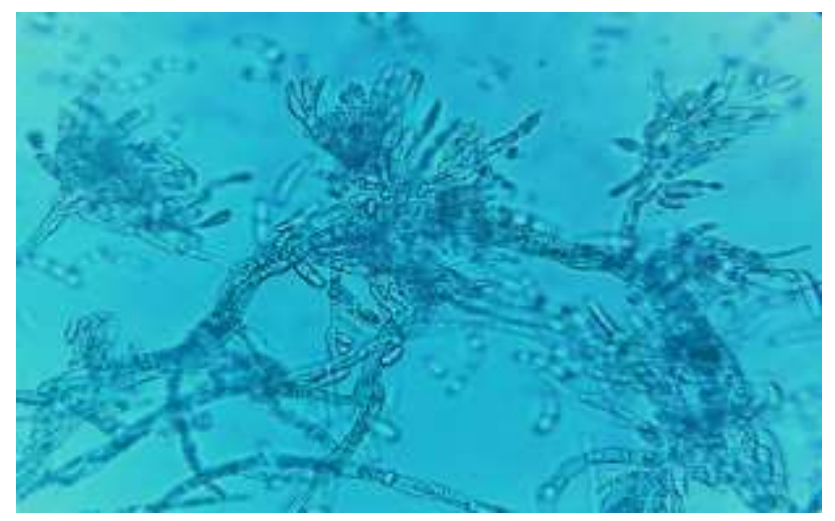

Figure 11 Observation of ascocarps and conidia of Colletotrichum sp

Source (Martínez-Scott, 2020)

\section{Fusarium}

The isolates obtained from Fusarium showed a great variability of colorations, white, cream, slightly yellowish, orange, reddish-brown, carmine red, wine red, violet, pink, purple and salmon, lilac, and even bluish colonies. This pigmentation can be given by the coloration of the mycelium or by the diffusion of some pigment in the culture medium in which the fungus develops (Villanueva et al., 2013). Figures 12 shows the growth of isolate M11.4.

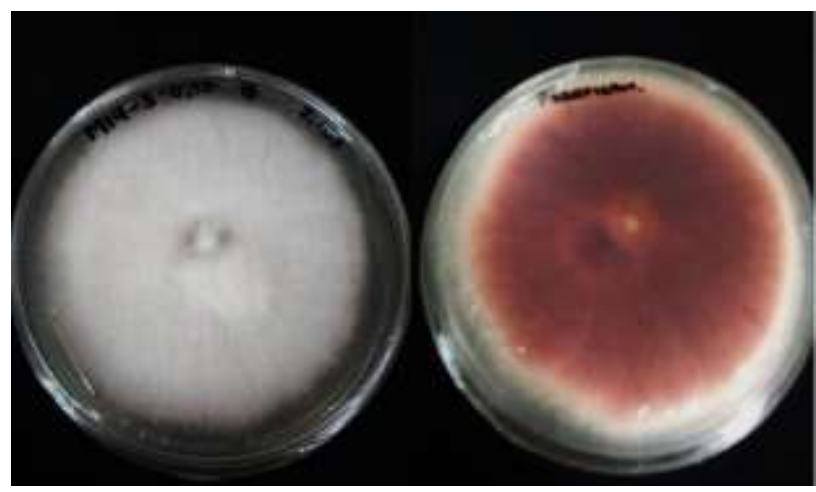

Figure 12 Growth of the fungus Fusarium $s p$. on PDA medium

Source: (Martinez-Scott, 2020)

Microconidia were septum-shaped with flattened base, without septa, produced in short chains. Macroconidia were elongated, relatively straight, with thin walls, curved apical cell and slightly developed basal cell. The polyphallae were long. All features observed under the optical microscope (40X) of were consistent with those reported by Leiva et al. (2017).

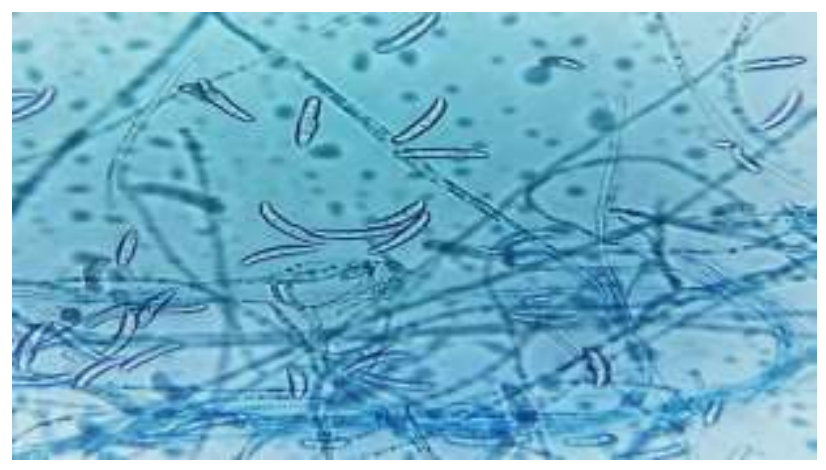

Figure 13 Observation of macroconidia of Fusarium $s p$ Source: (Martinez-Scott, 2020)

Most of the isolates presented colonies with wavy and regular edges, with lobed plush texture.

\section{Lecanicillium}

It was observed that colonies on PDA culture medium are usually white or yellowish, with a cottony appearance; however, the culture medium changes to yellow as the fungus grows and sporulates, which was achieved 10 days after sowing (Cañedo and Ames, 2004).

Figure 14 shows the growth of isolate M6, 1, on PDA, while Figure 15 shows microscopic structures of Lecanicillium sp 15 days after sowing. 


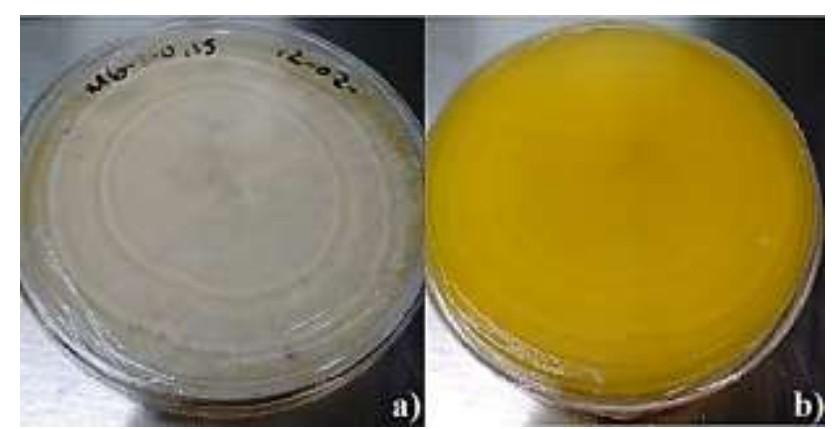

Figure 14 Macroscopic characteristics of the fungus Lecanicillium sp, a) front and b) back of the colony Source: (Martinez-Scott, 2020)

This genus presented solitary or verticillate and prostrate conidiophores, which apically carry masses of hyaline, subglobose, oval, falcate, fusiform, subcylindrical unicellular, non-adhesive conidia and do not present latency structures, results similar to those found by Zare et al. (2000).

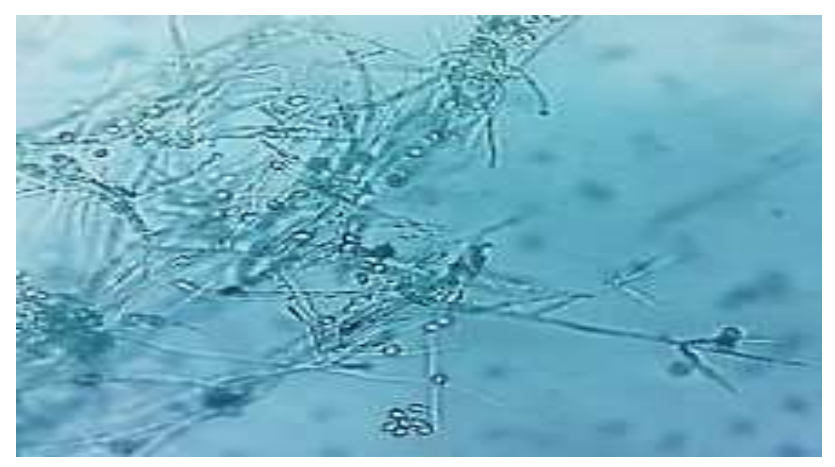

Figure 15 Observation of conidiophores and conidia of Lecanicillium $s p$

Source: (Martinez-Scott, 2020)

\section{Metarhizium}

According to the macro and microscopic characteristics of Metarhizium described by Metschnikoff Sorokīn in 1879 and in the results obtained in this research, this genus, presented a greenish coloration, with a cottony mycelium, high topography, rapid growth and on the reverse side a neon orange color. Figures 16 and 17 show the growth of isolate M5.1 and its microscopic characteristics.

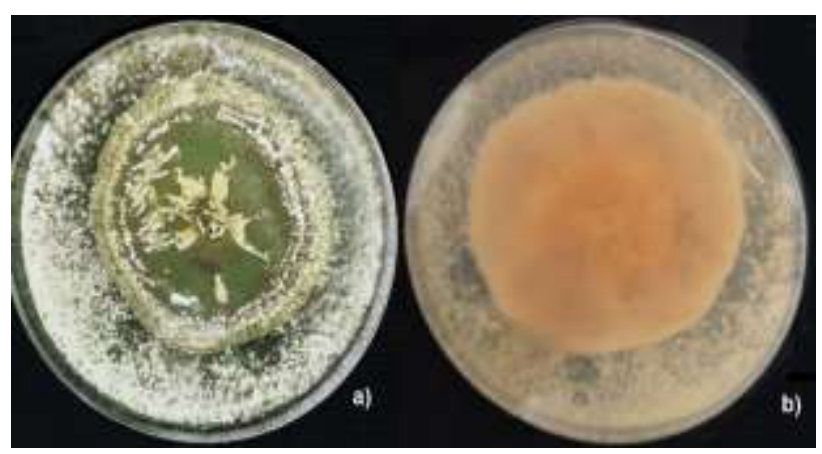

Figure 16 Growth of Metarhizium sp. on Sabouraud Agar at 10 days a) front and b) reverse

Source: (Martinez-Scott, 2020)

Initially the pigmentation of the conidia was white, turning to yellow in early conidial development (4-7 days) and then changing to a greenish color when the conidia were mature. According to Domsch and Gams, (1980), conidia can be hyaline or lightly pigmented olive green with a size of 7-9 $\mu \mathrm{m}$ long and 4.5-5 $\mu \mathrm{m}$ wide.

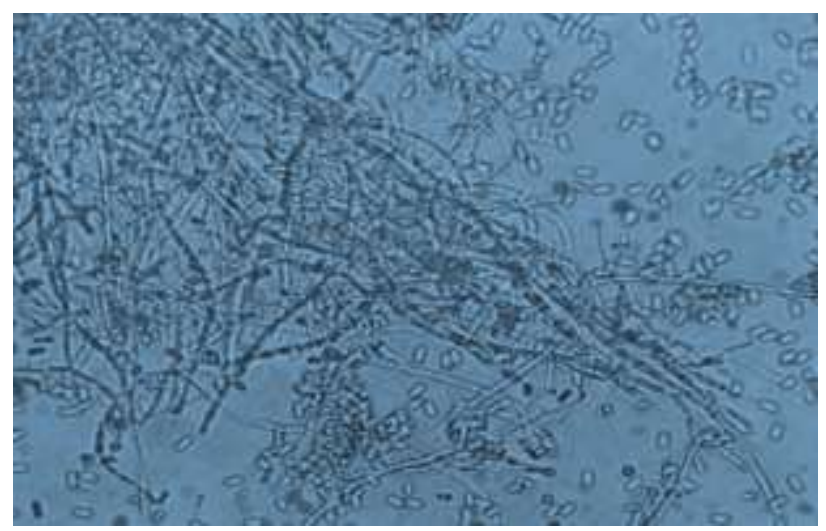

Figure 17 Observation of mycelium and conidia of Metarhizium sp

Source: (Martinez-Scott, 2020)

Confirmation of Metarhizium spp. isolates was performed by inoculating budworm (Spodoptera fugiperda) larvae that were being worked on in another investigation. The insect fungus was reisolated and its microscopic characteristics were observed.

\section{Mucor}

The colonies were circular, uniform and with abundant aerial mycelium of white color, with a cottony texture; this color was also observed on the back of the box. They are colonies of unlimited size (i.e., they cover the entire culture medium). Initially they are white, but as the sporangia are born, the color of the box begins to become darker, with a hairy cottony appearance, results consistent with Bonifaz, (2012) and Arenas, (2008).

MARTÍNEZ-SCOTT, Marcia Maribel, ZÚÑIGA-MALDONADO, Walter Manuel and MORENO-ZACARÍAS, Pedro Eduardo. Isolation and identification of microscopic fungi of agricultural importance in the Tetillas hill in Salvatierra, Guanajuato. Journal of Quantitative and Statistical Analysis. 2021 
M6,1.

Figures 18, shows the growth of isolate

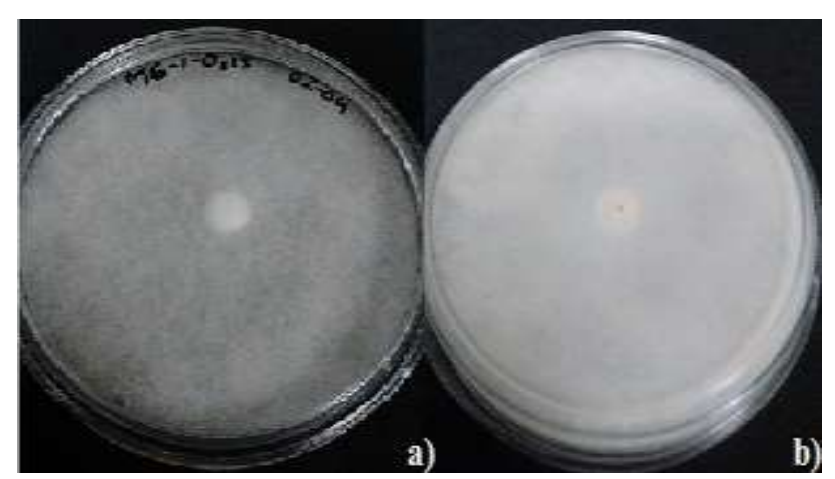

Figure 18 Growth of Mucor sp. on PDA

Source: (Martinez-Scott, 2020)

Figure 19 shows a macrosiphoned mycelium, coenocytic, hyaline, with sporangia. The columella of hyaline, almost spherical appearance presented a remnant collarete of the sporangial wall. Sometimes it can present chlamydoconidia, which can be confused with septa; being a Zygomycete it presents sporangiospores between 3 and $5 \mu \mathrm{m}$ in diameter, inside sporangia between 20 and 80 $\mu \mathrm{m}$, with a small but very ovoid columella (Bonifa, 2012).

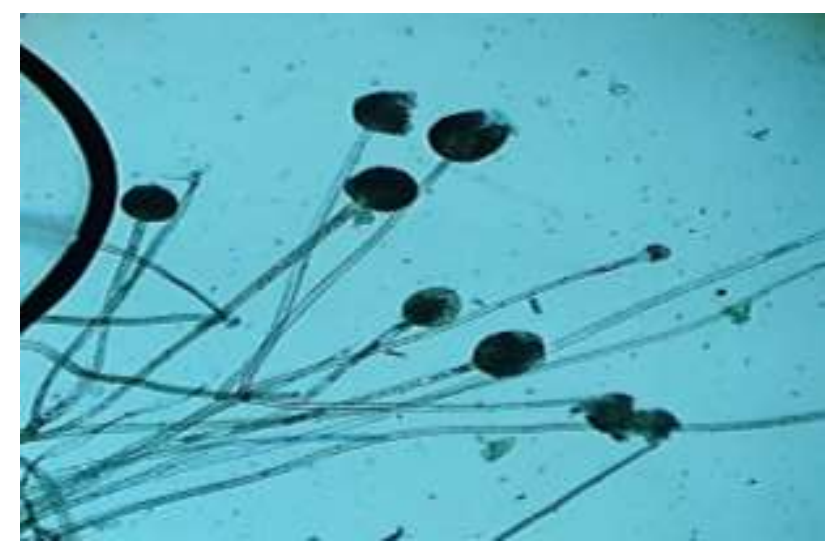

Figure 19 Observation of sporangia and endospores within Mucor sp. Small columella with a hyaline sporangium

Source: (Martinez-Scott, 2020)

\section{Penicillium}

Penicillium colonies were fast growing, filamentous and hairy, woolly or cottony in texture. Initially the colonies presented a white coloration and later, some isolates changed shades with days, from bluish-green, gray-green, to olive-gray, yellowish to pinkish. The reverse sides of the colonies varied from pale, yellowish or reddish, data that agree with those described by Pitt, (2000).
Figures 20 and 21 show the growth of Penicillium on PDA, as well as the microscopic structures of isolate M20.2.

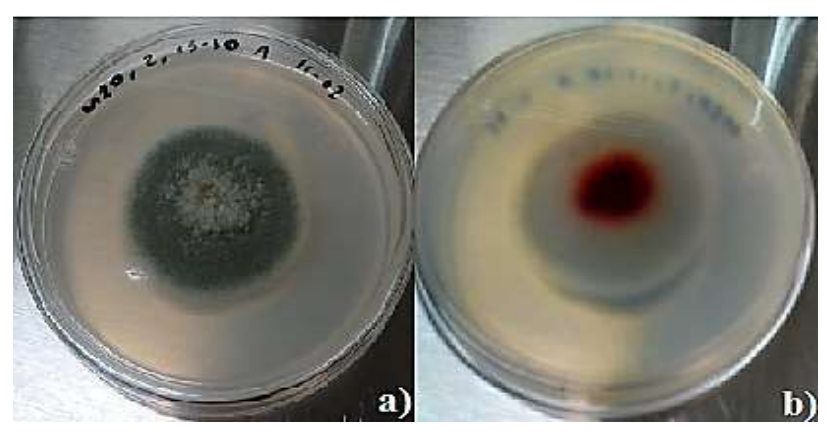

Figure 20 Growth and development of Penicillium sp. on PDA

Source: (Martinez-Scott, 2020)

Some Penicillium isolates presented hyaline septate hyphae with simple or branched conidiophores, metulae, phialides and conidia. Metulae are secondary ramifications that form on the conidiophores. Metulae carry flaskshaped phialides. The arrangements of the phialides at the tip of the conidiophores had a "penicilli" or brush. Round, unicellular, unbranched chain-like conidia were observed at the end of the phialides (Pitt, 2000).

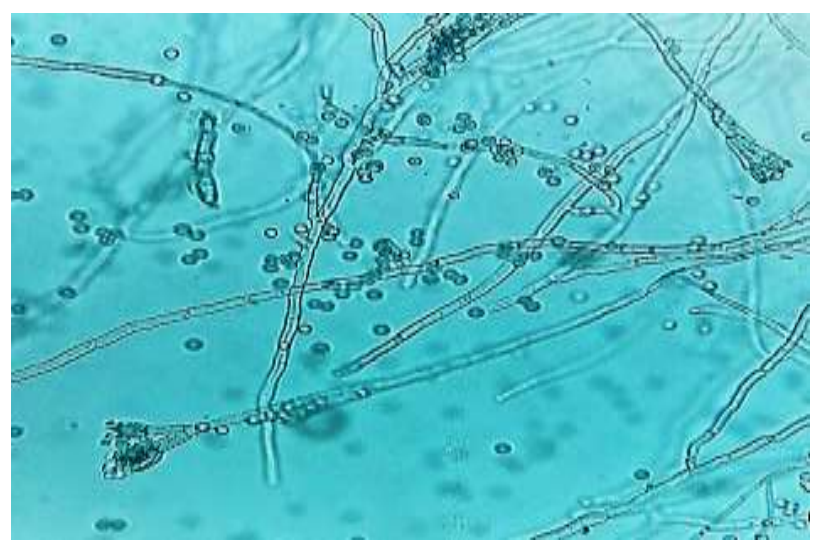

Figure 21 Observation of conidiophores, metulae, phialides and conidia of Penicillium sp.

Source: (Martinez-Scott, 2020)

\section{Paecilomyces}

Colonies showed a white color with a flat topography, which became yellowish and cottony. The reverse side was initially white and eventually changed to a cream color, similar characteristics were described by Bainier in 1907 when he first identified the genus Paecilomyces. 
Figure 22 shows the growth and development of isolate M6.1 on the seventh day of incubation.

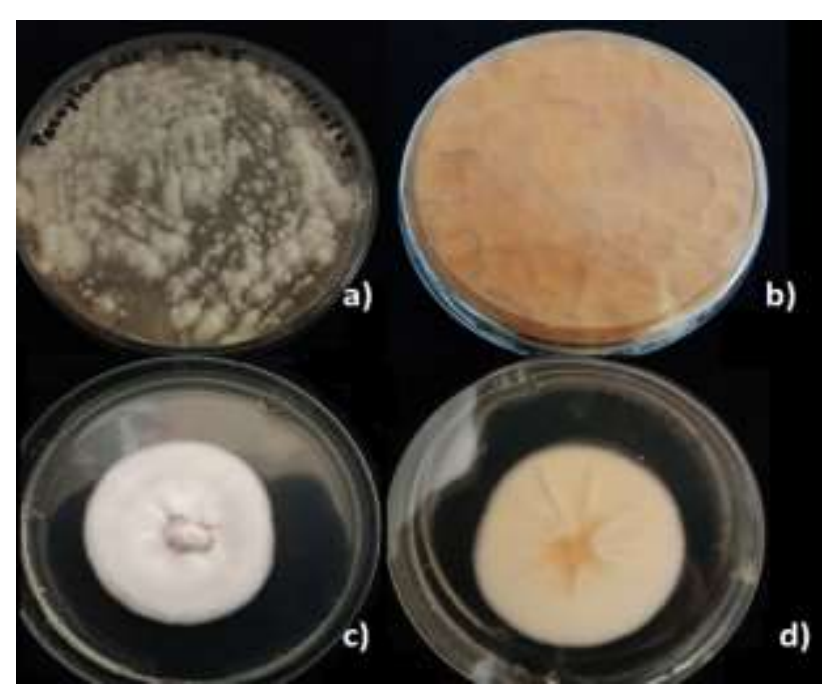

Figure 22 Growth and development of Paecilomyces $s p$. on PDA 1) and b) and on Sabouraud agar c) and d) Source: (Martinez-Scott, 2000)

The isolates presented hyaline to yellowish, septate, thin-walled hyphae. Most of them presented verticillate or irregularly branched ramifications, carrying in their terminal part groups of phialides in each branch, which can also be solitary.

The phialides consist of a cylindrical or swollen basal portion, thinning abruptly to form a very conspicuous neck. Conidiophores bear chains of conidia; hyaline, unicellular and ovoid in shape.

Brady (1979) and Marchal (1987) report that there are significant differences between the mean values of spore size in both the width and length, but not in the width of the hyphae; but there are differences between the length of the two, as well as in the width of the conidiophore.

These authors suggest that the size of the conidia ranges between 1-2 mm wide and 3-4 $\mathrm{mm}$ long approximately, with hyphae of 1-1.5 $\mathrm{mm}$ wide and 3.5-4.4 $\mathrm{mm}$ long, and conidiophores of $1.5-3 \mathrm{~mm}$ wide.

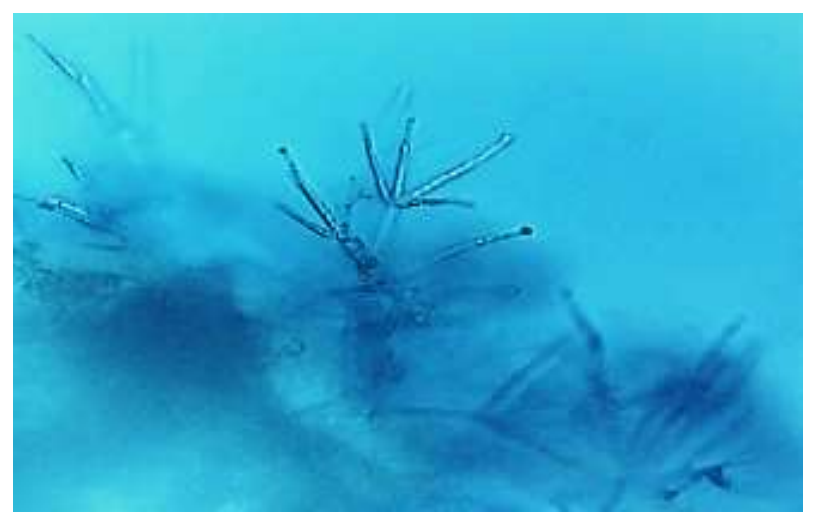

Figure 23 Observation of conidiophore, phialides and conidia of Paecilomyces sp. (40X magnification) Source: (Martinez-Scott, 2000)

\section{Phytophthora}

The isolates of the colonies developed on PDA were compact, with abundant aerial hyphae, long, cottony and smoothly radiated, with the presence and development of sclerotia after 15 days, and the reverse side was light brown, characteristics consistent with those described by Tuset, (1977).

Figures 24 and 25 show the growth and development of the fungus on PDA medium on the front and back of the plate, as well as the microscopic structures of the M13.5 isolate.

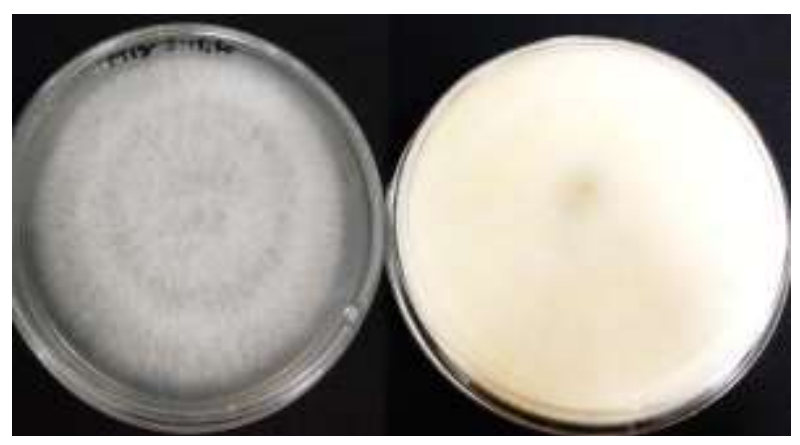

Figure 24 Growth and development of Phytophthora $s p$. on PDA medium seven days after sowing Source: (Martinez-Scott, 2000)

The microscopic characteristics of this genus showed a hyaline mycelium, branched, irregular in diameter, not elongated or with shallow transverse slits, with sectors presenting swellings and obpyriform to elongated vesicles. 


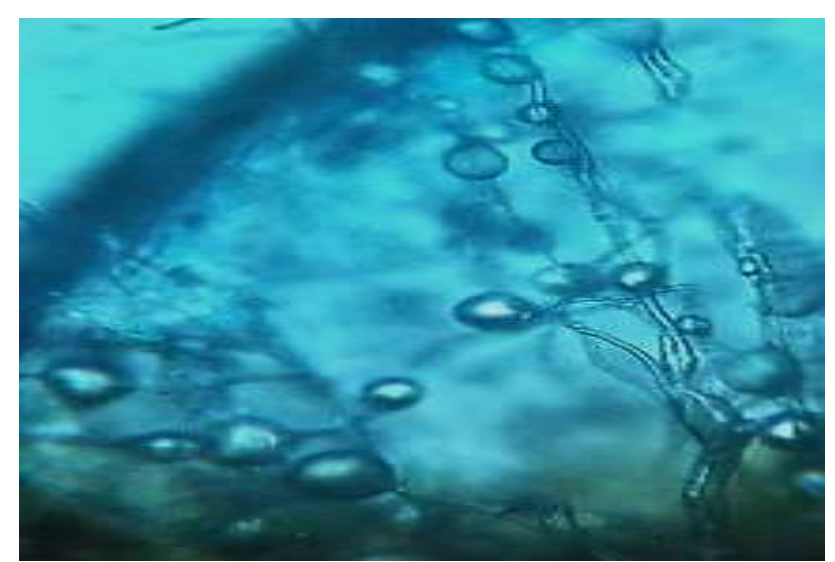

Figure 25 Observation of sporangium in sporangiophore of Phytophthora sp. (magnification 40X)

Source: (Martinez-Scott, 2000)

\section{Pythium}

According to the macro and microscopic characteristics of Pythium described by Pringsheim in 1858 and the results obtained in this investigation, the colony growth in the culture medium was white, with a radial shape, cottony texture, high topography, moderate growth and a white color on the back of the plate. Figures 26 and 27 show the macro and microscopic structures of the M13.5 isolate.

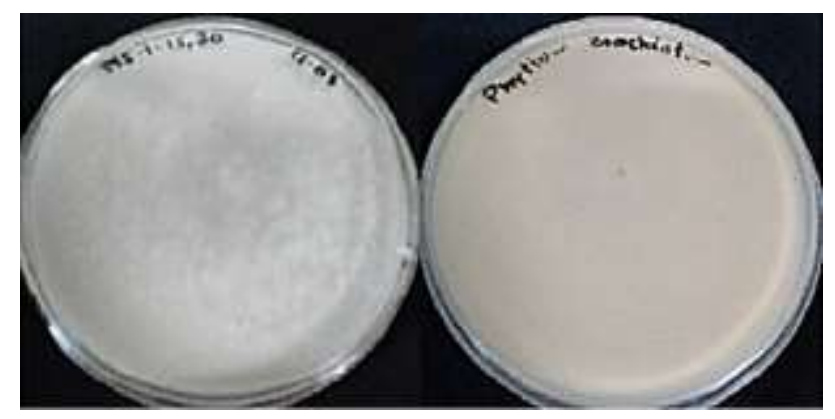

Figure 26 Growth and development of Pythium $s p$. on PDA medium

Source: (Martinez-Scott, 2000)

Pythium $s p$. is a fungus with oogonia generally intercalary, subglobose, 14-27 $\mu \mathrm{m}$, often in chains. It has hyphae without septa. It also has antheridia numbering 1-2 per oogonium, monoclinous or diclinous. Oospores aplerotic, 13-23 $\mu \mathrm{m}$ in diameter, smooth-walled and 1-1.5 $\mu \mathrm{m}$ thick. Sporangia subglobose or ellipsoid, intercalary or terminal, $12-33 \mu \mathrm{m}$ in diameter. They have a single oospore (Alexopoulos et al., 1996).

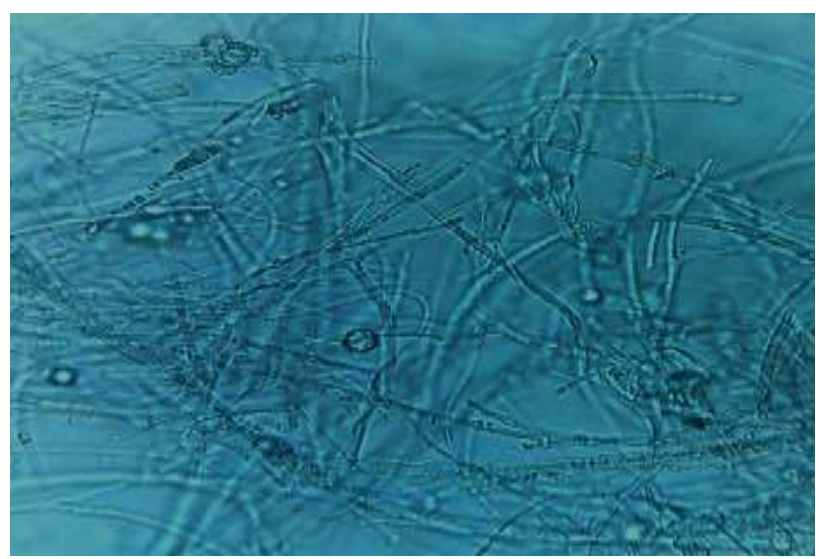

Figure 27 Observation of antheridium and oogonium of Pythium sp. (magnification 40X)

Source: (Martinez-Scott, 2000)

\section{Trichoderma}

Persoon in 1794 described the genus Trichoderma as a fast growing fungus, the isolates covered the surface of the PDA plates in 5 days at a temperature of $26 \pm 1^{\circ} \mathrm{C}$ with a green coloration and radial growth, similar characteristics that were obtained in this investigation. The colonies initially formed cottony pustules of a white color, later compacted and sporulated taking on a green color, granular texture, with branched conidiophores visible around the pustule. Not all the isolates presented the characteristic coconut odor, but most of them did present this characteristic. The reverse of the colonies showed a yellowish-brown coloration, results that agree with the descriptions made by (Gams and Bissett, 1998).

Figures 28 and 29 show the growth of Trichoderma on PDA and the microscopic characteristics of the isolate M6.03.

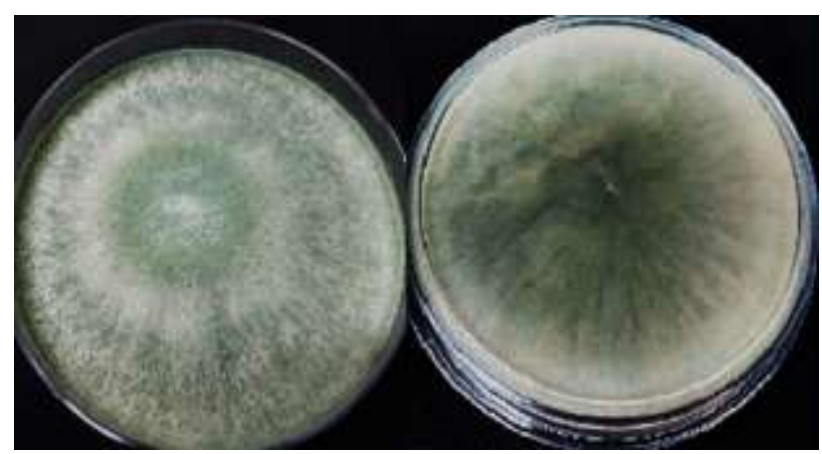

Figure 28 Growth of Trichoderma sp. seven days after sowing

Source: (Martinez-Scott, 2000) 
The isolates showed that this genus develops concentric rings, septate hyphae, hyaline, intricate conidiophore, whorls formed by five phialides, of ampuliform form, no intercalary phialides were observed. The conidia showed smooth wall, globose to subglobose, olive green, with terminal and intercalary chlamydospores, globose to subglobose. The characteristics of the isolate correspond to the description given by Barnett and Hunter (1987).

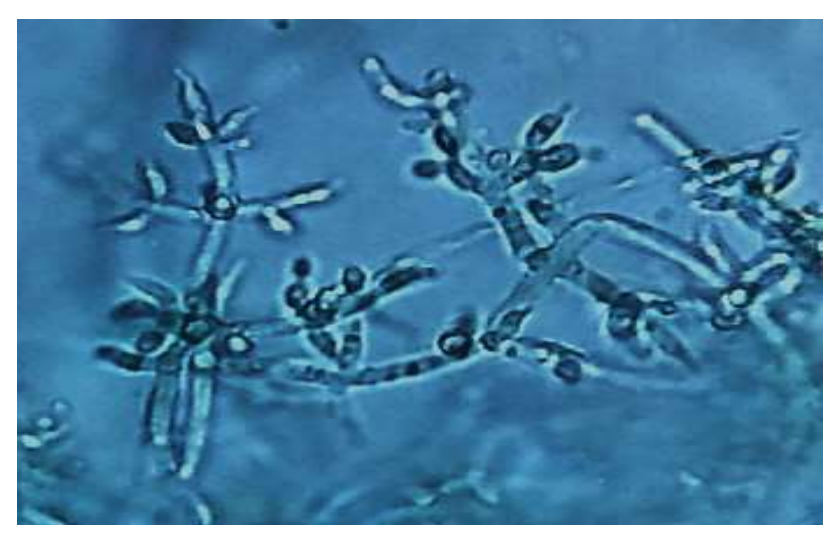

Figure 29 Observation of hyphae, conidiophores, phialides and conidia of Trichoderma $s p$.

Source: (Martinez-Scott, 2000)

\section{Trichophyton}

Malmsten in 1848 described the colonies of Trichophyton of reddish color in obverse and reverse, although some of his isolates showed white colorations with the reverse of reddish color (frequent red pigment). In the isolates obtained in this investigation, the reverse side of the colony was pinkish-red, but sometimes yellow-brown and reddish-wine or violet, and some colonies even lacked pigmentation.

Figure 30 shows the growth of the fungus with a finely hairy appearance, taking on a velvety form. The surface showed shallow radial grooves. The margins are usually netted and the radial extensions give it a frayed appearance. When the colonies are white they present greater aerial mycelium that gives them a cottony appearance.

The reverse side is stained with red pigment that diffuses to the edges, forming a red stripe surrounding the central white mass. According to Tartabinia et al., 2013 the colonies grow well on most common culture media.

Figures 31 and 32, show the growth on PDA culture medium and the microscopic structures of isolate M5.1.
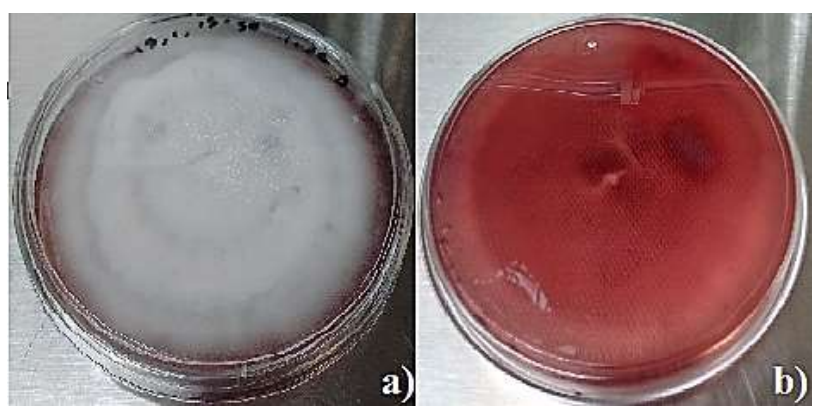

Figure 30 Box-filling characteristics on PDA of Trichophyton sp. a) obverse and reverse of the colony on the seventh day of incubation Source: (Martinez-Scott, 2000)

Under the microscope, the presence of pyriform and spherical microconidia and some macroconidia was observed.

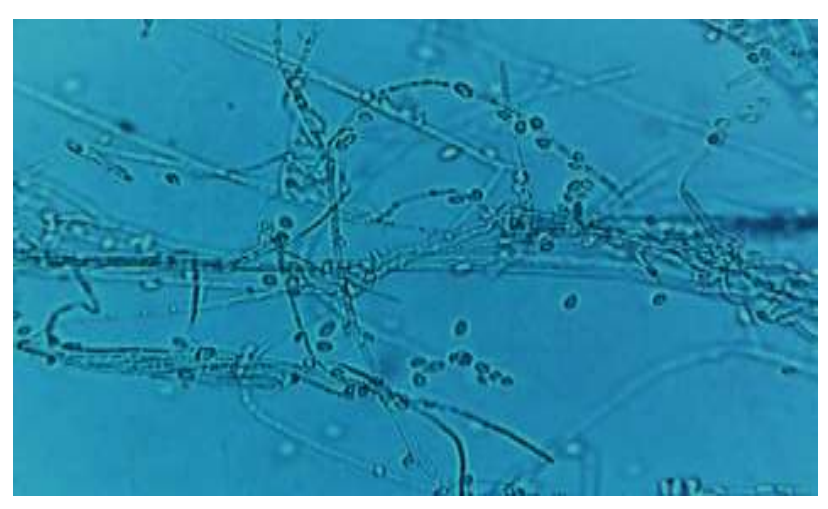

Figure 31 Hyphae and microconidia of Trichophyton $s p$. (magnification 40X)

Source: (Martinez-Scott, 2000)

\section{Verticillium}

According to the macro and microscopic characteristics of Verticillium described by Nees in 1817 and in the results obtained in this investigation, a grayish to blackish coloration was observed in the colonies, due to the formation of microsclerotia, a cottony texture, flat topography and a creamy yellow reverse color according to the keys of Barnett and Hunter, (1998) and Barron, (1968). Figure 32 shows a slow growth of isolate M6.1 on PDA seven days after sowing.

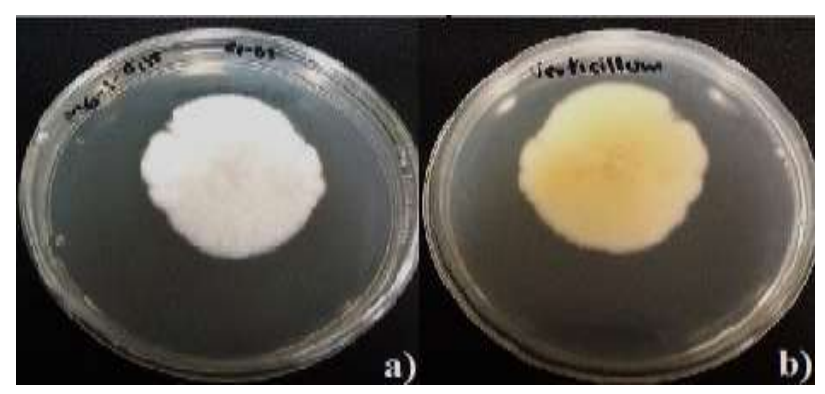

Figure 32 Growth and development characteristics of Verticillium $s p$.

Source: (Martinez-Scott, 2000)

MARTÍNEZ-SCOTT, Marcia Maribel, ZÚÑIGA-MALDONADO, Walter Manuel and MORENO-ZACARÍAS, Pedro Eduardo. Isolation and identification of microscopic fungi of agricultural importance in the Tetillas hill in Salvatierra, Guanajuato. Journal of Quantitative and Statistical Analysis. 2021 
The conidiophores are hyaline, erect and carry a mass of conidia apically in each verticillate phialides in 2-3 fertile portions. The conidia are hyaline, smooth-walled, ellipsoidal, unicellular, non-septate. The above microscopic morphology characteristics place the pathogen as belonging to the genus Verticillium (Watanabe, 2010; Campbell et al., 2013).

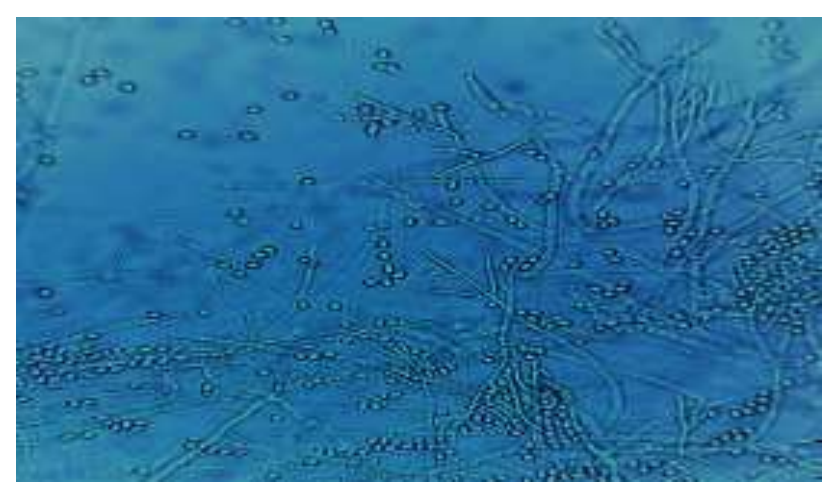

Figure 33 Conidiophores, phialides and conidia of Verticillium sp. (40X magnification)

Source: (Martinez-Scott, 2000)

\section{Discussion}

The diversity of mountain filamentous fungi in Salvatierra Guanajuato is unknown, this research is a precursor in the isolation and identification of soil fungal communities in Cerro las Tetillas. Despite of we might expect, in environments apparently hostile to life, such as mountain ecosystems, the microbial communities in their soils are very abundant and possess a striking genetic and functional diversity (Lipson et al., 2002; Nemergut et al., 2005; Lipson, 2007).

Due to the rapidly changing conditions in mountain ecosystems from season to season, microbial communities in these soils show significant variations in abundance, composition and functioning over very short periods of time (Wardle, 1998).

During winter and early spring, changes in microbial communities are related to soil temperature, as well as to the availability of $\mathrm{C}$ and $\mathrm{N}$ sources. During summer, changes in the microbial community have been related to processes of interaction with plants, in particular with processes of partitioning and competition for nutrients and with changes in the availability of $\mathrm{C}$ sources from plants through root exudates or litter quality (Bardgett et al., 2005).
According to results, the pHof the soils of Tetillas Hill for isolation of filamentous fungi is optimal, since it is in the range of 6.1 to 6.8 (neutral) (Kavanagh, 2005; Diemer, 1996). This should be so because, according to Cochrane, 1963, a high pH greatly impairs the development of fungi due to thesolubility of metals, and at low $\mathrm{pH}$ the enzyme systems, the entry of essential vitamins, organic acids and the uptake of minerals are affected.

The results indicate that the E. C. values obtained per stratum varied, demonstrating that the areas less disturbed by human activities are those with lower electrical conductivity. The values obtained per stratum were $1.12 \mathrm{dS} / \mathrm{m}$, $1.29 \mathrm{dS} / \mathrm{m}$ and $1.45 \mathrm{dS} / \mathrm{m}$ for the high, medium and low stratum respectively, indicating that the soils of Cerro Tetillas are not very saline or with a normal salinity, since it is less than $2 \mathrm{dS} / \mathrm{m}$. (NOM-021-RECNAT-2002). The importance of evaluating the E.C. of the soil is due to theeffects of salinization, since they can be very serious, both in economic and social terms, as well as on organisms and microorganisms(Steubing et al., 2002).

\section{Conclusions}

A total of 113 axenic strains of filamentous fungi corresponding to 16 genera were isolated from Cerro las Tetillas in Salvatierra, Guanajuato, Mexico.

The difficulty of taxonomicidentification of fungi is high, which is why we only reached until genus, because there are many factors that affect the growth and sporulation of the fungus in the laboratory, such as the requirements of light, humidity, temperature, $\mathrm{pH}$, nutrients and vitamins to survive, grow and reproduce. Therefore, it is advisable to use various culture media that are specific for sporulation (Kirk et al. 2008).

The confirmation of entomopathogenic fungi was carried out through inoculation in insects such as whitefly (Bemisia tabaci) and codling moth (Spodoptera fugiperda). December 2021 Vol.8 No.23 1-16 
The greatest diversity of fungi isolated were Trichoderma and Fusarium. Outstanding genera were present in the three strata of the hill (high, medium and low). Trichoderma is an antagonistic fungus that possesses Trichoderma mechanisms involve mechanisms of action such as microparasitism, antibiosis, competition for nutrients, among others (Ghazanfar et al., 2018), while Fusarium presents a wide range of hosts and structures of vital importance for thesurvival of the genus in the soil under adverse conditions. For example, Trichoderma which is a soil and wood saprophyte and growth in soilis very fast and has the ability to be found in anyclimate, soil type and altitudes reason why it wasfound in all strata sampled (Rifai, 1969). Trichoderma is a mycoparasite of other fungi and is used as a biocontroller of Rhizoctonia, Fusarium, Pythium, Verticillium (Infante et al., 2009).

Fusarium is a multifaceted fungus that has a wide range of hosts and this allows it to have reproductive polycycles, which ensures its permanence in the soil.

Factors that influence the diversity and distribution of fungi are: native vegetation, $\mathrm{pH}$, electrical conductivity and human disturbance, as well as rainfall runoff.

Genera such as Alternaria, Aspergillus, Beauveria, Cladosporium, Colletotrichum, Lecanicillium, Metarhizium, Mucor, Paecilomyces, Phytophthora, Pythium, Trichophyton and Verticillium were isolated in smaller proportions, indicating that they also inhabit these soils.

Four genera of entomopathogenic fungi, Beauveria, Lecanicillium, Metarhizium and Paecilomyces, were isolated and identified as having potential for use in biological pest control.

\section{Acknowledgements}

To the Instituto Tecnológico Superior de Salvatierra for the facilities provided for carrying out this research.

\section{References}

Alexopoulos C.J., Mims C.W., y Blackwell M. (1996). Introductory Mycology. 4 a edn. John Wiley \& Sons, Inc., New York. 868 pp.
Aguirre-Acosta, Elvira, Ulloa, Miguel, Aguilar, Samuel, Cifuentes, Joaquín, \& Valenzuela, Ricardo. (2014). Biodiversidad de hongos en México. Revista Mexicana de Biodiversidad, vol. 85, 2014, pp. 76-81.

Arenas, R. (2008). Micología médica ilustrada, Capítulo 22 Zigomicosis. Ed. McGrawHill: México, DF. 247-251, 403 p.

Bailey, J. A., Jeger, M. J. (1992). Colletotrichum: Biology, Pathology and Control. For British Society for Plant Pathology. Cabi; Ed. First, 402 P. England.

Barnett, H y Hunter, B. (1972). Illustrated Genera of Imperfect Fungi. EE.UU. Burgess Publ. Co. 241p.

Barnett, H. L., and B. B. Hunter. (1998). Illustrated Genera of Imperfect Fungi. American Phytopathological Society Press. St. Paul, Minnesota. USA. 218 p.

Barron, G. L. (1968). The genera of Hyphomycetes from soil. Baltimore, Canadá: The Williams and Wilkins Co. ISBN 15510520169781551052014.

Bissett, J. (1984). A revision of the genus Trichoderma, I. Section Longibrachiatum sect. nov. Canadian Journal of Botany, vol. 62, pp. 924-931.

Bissett, J. (1991). A revision of the genus Trichoderma, II. Infrageneric classification. Canadian Journal of Botany, vol. 69, pp. 23572372.

Bonifaz, A. (2012). Micología médica básica, Capítulo 5 Hongos Contaminantes, McGrawHill: México, DF. pág. $62-63,600$ p.

Bonkowski, M., Griffith, B. S. y Ritz, K. (2000). Food preference of earthworms for soil fungi. Pedobiología, vol. 44, pp. 666-676.

Botero, M. (1999). "Estudios Biológico y Epidemiológicos de la Antracnosis (Colletotrichum gloesporioides Penz) en Tomate de Árbol y Desarrollo de Alternativos para su manejo integrado en Colombia". Financiado por Pronatta. Pp 15-18. 
Brady, B. (1979). Paecilomyces fumosoroseus CMI. Descriptions of Pathogenic Fungi and Bacteria $\mathrm{N}^{\circ}$ 614. Commonwealth Agricultural Bureaux.

Bardgett, R.D., Bowman, W.D., Kaufmann, R., Schmidt, S.K. (2005). A temporal approach to linking aboveground and belowground ecology. Trends Ecol Evol 20: 634-641

Cabello, M., Arambarri, A. (2002). Diversity in soil fungi from undisturbed and disturbed Celtis tala and Scutia buxifolia forests in the eastern Buenos Aires province (Argentina). Microbiol Res. 157(2): 115-125.

Campbell, C. K, Johnson, E.M. and Warnack, D. W. (2013). Identification of Pathogenic Fungi. Second Edition. Wiley-Blackwell. Health Protection Agency. U.K. 337 p.

Cañedo, V., y Ames, T. (2004). Manual de Laboratorio para el Manejo de Hongos Entomopatógenos. Centro Internacional de la Papa. Perú.

Cifuentes, J. (2008). Hongos. Catálogo taxonómico de especies de México. In Capital natural de México, Vol. 1: conocimiento actual de la biodiversidad. Conabio, México. CD1.

Conabio. (2019). Hongos. Recuperado de: https://www.biodiversidad.gob.mx/especies/gfa milia/4/index.

Cochran, W.G. (1963). Técnica de muestreo. Segunda edición, John Wiley and Sons Inc., Nueva York.

Cruz Choappa, R., Piontelli Laforet, E., Vieille Oyarzo, P., y Carvajal Silva, L. (2016). Identificación de Alternaria botrytis (Preuss) Woudenberg y Crous. Revista argentina de microbiología. 48(2):182-183, ISSN: 03257541.

Dick, W. M. (1990). Keys to Pythium. Ed. Dick, M. W. Department of Botany. School of Plant Sciences. University of Reading. Reino Unido. $64 \mathrm{p}$.

Diemer, M. (1996). Microclimatic Convergence of High-Elevation Tropical Páramo and Temperate-Zone Alpine Environments Title. J Veg Sci. 6:821-830.
Domsch, K. H., Gams, W., Anderson, T. H. (1980). Compendium of soil fungi. Academic Press, London. 2nd edition updated by W. Gams, 2006. Centraalbureau voor Schimmelcultures, Utrecht, in press.

Domsch, K. H., Gams, W. y Anderson, T. 2007. Compendium of Soil Fungi, 2nd edition,

Gams, W. y J. Bissett. (1998). Morphology and identification of Trichoderma. Harman, G.E., Kubicek, C. P. (eds) Trichoderma and Gliocladium. London: Tayler and Francis.

Gams, W., Chistrensen, M., Onion, A.H.S., Pitt, J. I., Samson, R. A. (1985). Infrageneric taxa of Aspergillus. In: Advances in Penicillium and Aspergillus systematics. Plenum Press, Nueva York, EEUU. 55-64p.

Ghazanfar M. U., M. Raza, W. Raza and M. I. Qamar (2018) Trichoderma as potential biocontrol agent, its exploitation in agriculture: a review. Plant Protection 2:109-135.

Hawksworth, D. L. (2001). The magnitude of fungal diversity: 1.5 million species estimate revisited. Mycological Research 105:14221432.

Herrera, T. y Ulloa, M. (1990). El Reino de los Hongos, micología básica y aplicada. UNAMFondo de Cultura Económica, México, D. F. 552 p. ISBN: 9789681657376.

Humber, R. A. (1998). ARS Collection of entomopathogenic fungal culture. In: Systematic collections of the agricultural research service ( $\mathrm{J}$. R. Lichtenfels, J. H. Kirkbride y D. J. Chitwood, Eds.). USDA-ARS Misc. Publ., Washington, EUA, pp 8-12.

Infante, D., Martínez, B., González, N., Reyes, Y. (2009). Mecanismos de acción de Trichoderma frente a hongos fitopatógenos. Revista de Protección Vegetal, 24(1), 14-21. ISSN 2224-4697. Recuperado de: http://scielo.sld.cu/scielo.php?script=sci_arttext \&pid=S1010-27522009000100002.

Kavanagh, K. (2005). Fungi biology and applications. Thirt edition In Willey Blackwell. 267 p. ISBN: 978-1-119-37427-5. 
Kirk, P. M., Canon, P.F., Minter D.W., y Stalpers J.A. (2008). Ainsworth \& Bisby's Dictionary of the Fungi. 10 ed. International Mycological Institute, CAB International, Wallingford. 784 p. ISBN 9780851998268 Recuperado de: http://www.pherbal.com /public/user_data/files/Dictionary\%20of\%20the $\% 20$.

Lavelle, P., Spain, A.V. (2001). Soil ecology. Dordrecht, NL. Kluwer Academic Publishers. p. 654.

Leslie, J. F., Summerell, B. A., y Bullock, S. (2006). The Fusarium Laboratory Manual, Blackwell Publishers, Malden, MA. ISBN-13: 978-0-8138-1919-8. ISBN-10: 0-8138-1919-9. Recuperado de: https://es.slideshare.net/manuel sandovalb/the-fusarium-laboratory-manual16817601 .

Lipson, D. A. (2007). Relationships between temperature responses and bacterial community structure along seasonal and altitudinal gradients. Microbial Ecol 59: 418-427.

Lipson, D.A., Schadt, C. W., Schmidt, S.K. (2002). Changes in Soil Microbial Community Structure and Function in an Alpine Dry Meadow Following Spring Snow Melt. Microbial Ecol 43: 307-314.

Marchal, M. (1987). Contribution a lłetudé de la biologie d $\varnothing$ Otiorhynchus sulcatus. F (Col: Cucurlionidae) invertaire, incidence et perspectives d'utilisation des Champignons entomopatogenes. Suivie d'une mise au poit monografique sur le genre Otiorhynchus», París 56.

Mueller, G., Billis, G. Foster, M. (2004). Biodiversity of fungi: inventory and monitory methods. Elsevier Academic Press London 777 p.

Nemergut, D.R., Costello, E.K., Meyer, A.F., Pescador, M.Y., Weintraub, M.N., Schmidt, S.K. (2005). Structure and function of alpine and arctic soil microbial communities. Research in Microbiology 156: 775-784.
Pescasa-Quisbert, Fernando, Loza-Murguia, Manuel Gregorio, Bonifacio-Flores, Alejandro, Vino-Nina, Lourdes, \& Serrano-Canaviri, Teófilo. (2017). Comunidad de hongos filamentosos en suelos del Agroecosistema de K'iphak'iphani, Comunidad ChoquenairaViacha. Journal of the Selva Andina Research Society, 8(1), 2-25. Recuperado de http://www.scielo.org.bo/scielo.php? script=sci _arttext\&pid=S2072-92942017000100002 \&lng= es\&tlng=es.

Pfenning. L., y Magalhães. L. (2012). Hongos del suelo saprófitos y patógenos de plantas. Manual de suelos tropicales. Recuperado de: https://micrositios.inecc.gob.mx/publicaciones/l ibros/667/cap8.pdf.

Piontelli, E. (2012). Manual de microhongos filamentosos comunes: Universidad de Valparaíso, Escuela de Medicina, Chile: 500pp. Recuperado de: http://www.rccb.uh.cu/index. php/RCCB/article/view/74/144.

Pitt, J. I. (2000). A Laboratory Guide to Common Penicillium Species, 3rd edition, CSIRO, North Ryde, Australia. Recuperado de: http://www.asmscience.org/content/book/10.11 28/9781555815912.ch25.

Rifai. M. A. (1969). A revision of the genus Trichoderma. Mycological Papers, 116: 1156.

Rodríguez, P.; Soares, C.; Kozakiewicz, Z.; Paterson, R.; Lima, N.; Venâncio, A. (2007). Identification and characterization of Aspergillus flavus and aflatoxins. Communicating Current Research and Educational Topics and Trends in Applied Microbiology. Mendez-Vilas (Ed). 527-534.

Rodríguez Guzman, Pilar. Ma. (2001). Biodiversidad de los hongos fitopatógenos del suelo de México. Acta Zoológica Mexicana, ISSN: 0065-1737, Recuperado de: http://www.acuedi.org/ddata/2222.pdf.

Sivila, R., Hervé, D. (1999). Análisis de la microbiota en suelos cultivados del Altiplano central. Primer Congreso Boliviano de la Ciencia del Suelo. La Paz, Bolivia. p. 5-14.

Steubing, L., Godoy, R., Alberdi, M. (2002). Métodos de ecología vegetal. Editorial Universitaria. 345p. 
Tartabini, M., Bonino, G., Racca, L., Luque, A. (2013). Estudio taxonómico de aislamientos clínicos de Trichophyton en Rosario, Argentina. Revista Argentina de Microbiología. 45 (4) 248253.

Tsao, P. H., Erwin, D. C. y Bartnicki-Garcia, S. (1983). Phytophthora, its Biology, Taxonomy, Ecology and Pathology, APS Press, St. Paul, MN.

Tuset, J. J. (1977). Contribución al conocimiento del género Phytophthora De Bary en España. An. INIA/Ser. Prot. Veg.1:11-106.

Valencia, H. (1979). La microbiología del suelo y sus perspectivas. Boletín. Informativo. Departamento de Biología. (1): 1-18. Universidad Nacional de Colombia.

Vargas, M. (2003). Caracterización de tres cepas de Beauveria brongniartii (saccardo) petch y su virulencia en Phthorimea operculella (Séller) y Symmetrischema tangolias (Gyen). Tesis. Facultad de Ciencias Biológicas, Universidad Nacional Mayor de San Marcos. Lima-Perú. 78pp.

Wardle, D. A. (1998). Controls of temporal variability of the soil microbial biomass: A global-scale synthesis. Soil Biol Biochem 30: 1627-1637.

Watanabe, T. (2010). Pictorial atlas of soil and seed fungi: morphologies of cultured fungi and key to species (3.a ed.). Boca Raton, EE. UU., Londres, Inglaterra, y Nueva York, EE. UU.: CRC. ISSN: 0950-4125 Recuperado de: https://pdfs.semanticscholar.org/0435/fc4a $4 \mathrm{e} 42$ f556686f4890a6918ebb31799d9d.pdf. 